\title{
Gastroprotective Effects of Various Scrophularia striata Extracts on Ethanol-Induced Gastric Ulcer in Rats
}

\author{
Scrophularia striata Ekstrelerinin Ratlarda olușturulan Etanol-Nedenli Gastrik Ülser \\ Modeli Üzerindeki Gastroprotektif Etkileri
}

\author{
Maryam RAFIEI', Fatemeh NAMAZI2,", Hamid RAJAIAN1', Saeed NAZIFI3 \\ 1Shiraz University, School of Veterinary Medicine, Department of Basic Sciences, Shiraz, IRAN \\ 2Shiraz University, School of Veterinary Medicine, Department of Pathobiology, Shiraz, IRAN \\ ${ }^{3}$ Shiraz University, School of Veterinary Medicine, Department of Clinical Studies, Shiraz, IRAN
}

\begin{abstract}
This study was conducted to investigate the influence of various extracts of S. striata in ethanol-induced gastric ulcer model in rats. 100 male rats were divided into 10 groups and received the following medications: Normal control group without treatment; comparative standard control group received $20 \mathrm{mg} / \mathrm{kg}$ omeprazole; Groups 4-9 were given aqueous, hydroalcoholic and etheric extracts at 100 and $400 \mathrm{mg} / \mathrm{kg}$, respectively; vehicle control group given DMSO as solvent solution. After one hour all the rats (except normal control group) and also ulcer control group were given $4 \mathrm{~mL} / \mathrm{kg} 75 \% \mathrm{EtOH}$ solution to induce ulceration. The rats were sacrificed after one hour; the gastric mucosal injuries were estimated through assessment of the gross appearance of ulcer areas, histopathology and parameters including MDA, TAC, PGE ${ }_{2}$ and HSP70 in the gastric tissue homogenate. The ulcer control group showed severe mucosal injury compared with aqueous and etheric extracts which grossly showed significant reduction of ulcer areas and histopathologically showed marked reduction of mucosal necrosis, edema and leukocytes infiltration. A significant increase in the levels of HSP70, PGE ${ }_{2}$ and TAC with a reduction in the level of MDA was observed in the rats treated with etheric and especially aqueous extracts. The results of the present study revealed significant protection of $S$. striata towards ethanol-induced gastric mucosal injury.
\end{abstract}

Key words: Ethanol, Gastric ulcer, Gastroprotective, Scrophularia striata, Antioxidant, Histopathology

öz

Bu çalıșma, Scrophularia striata'nın farklı polaritedeki ekstrelerinin ratlarda etanol-nedenli gastrik ülser modelindeki etkisini araştırmak amacıyla yürütüldü. Yüz erkek sıçan 10 gruba ayrıldı: Normal kontrol grubu hayvanlarına hiçbir tedavi uygulanmadı; karşılaştırmalı standart kontrol grubuna 20 mg/kg omeprazol; grup 4-9'a sırasıyla 100 ve 400 mg/kg dozlarda sulu, sulu alkollü ve eterli ekstreler; taşıyıcı kontrol grubuna ise çözücü olarak DMSO uygulandı. Bir saat sonra ülser olușturmak için tüm ratlara (normal kontrol grubu dışında) ve ülser kontrol grubuna $4 \mathrm{~mL} / \mathrm{kg} \% 75 \mathrm{ETOH}$ verildi. Ratlar bir saat sonra sakrifiye edildi; gastrik mukozal hasarlar, gözle görünür ülser bölgelerinin tespit edilmesiyle, histopatolojik analizlerle ve mide dokusu homojenatında MDA, TAC, PGE 2 ve HSP70 belirlenmesiyle değerlendirildi. Ülser kontrol grubunda şiddetli mukozal hasar tespit edilirken, sulu ve eterli ekstre grubunda ülser alanlarında anlamlı küçülme, histopatolojik analizlerde mukozal nekrozda, ödem ve lökosit infiltrasyonunda azalma tespit edildi. Sulu ve eterli ekstre ile tedavi edilen ratlarda HSP70, PGE 2 ve TAC seviyelerinin anlamlı bir şekilde artıı̆ı, MDA seviyesinin ise azaldığı görüldü. Çalıșma sonuçları, etanol-nedenli gastrik mukozal hasara karşı Scrophularia striata'nın anlamlı derecede koruyucu etki sağladığını gösterdi.

Anahtar kelimeler: Etanol, Gastrik ülser, Gastroprotektif, Scrophularia striata, Antioksidan, Histopatoloji

\section{INTRODUCTION}

Peptic ulcer disease is one of the most common disruptions of the mucosal integrity of the stomach (a gastric ulcer) and small intestine (a duodenal ulcer) (1). It has generally been accepted that gastric ulcers are multifactorial and appear to be due to an imbalance among the aggressive factors (such as acid/pepsin, bile, alcohol, tobacco and caffeine, $H$. pylori infection, NSAIDs, stresses) and mucosal defensive mechanisms (including mucus secretion, bicarbonate production, mucosal blood flow, cellular repair mechanisms, prostaglandin $E$, growth factors) (2).

Peptic ulcer treatment using synthetic drugs (such as $\mathrm{H} 2$ blockers, proton pump inhibitors and NSAIDs) results in adverse effects, relapses and drug interactions (3). Therefore, herbal medicines containing active chemical components are considered as the main source of new drugs and appropriate alternatives for treatment of the various diseases including peptic ulcer. 
Scrophularia striata, commonly known as figwort, belongs to a family of flowering plants called Scrophulariaceae. It is native to Iran and grows wild in meadows, hillsides and impassable areas of Ilam Province (4). The Scrophulariaceae family consists of about 3000 species and 220 genera. Species of Scrophularia share square stems, opposite leaves and open two-lipped flowers forming clusters at the end of their stems (5).

Several chemical components including cinnamic acid, three flavonoids (quercetine, isorhamnetin-3-O-rutinoside and nepitrin) and one phenylpropanoid glycoside (acteoside 1) have been identified in the aerial parts of S. striata (6). It appears that some compounds isolated from this species have the inhibitory effects on a variety of malignant and inflammatory disorders (7). Hence, the present study was carried out to determine the gastroprotective effects of Scrophularia striata on ethanol-induced gastric ulcer.

\section{EXPERIMENTAL}

\section{Omeprazole}

In the present study, omeprazole was used as a comparative standard control drug for antiulcer study. The drug was dissolved in distilled water and administered orally to the rats at $20 \mathrm{mg} / \mathrm{kg}(5 \mathrm{~mL} / \mathrm{kg}$ ) according to previous study (8).

\section{Plant specimen and preparation of extraction}

The aerial parts of S. striata were collected from the Zagros mountain range, Kermanshah Province, in May 2014. The plant sample was authenticated and voucher specimen was deposited at the Herbarium of Faculty of Sciences, Kharazmi University, Tehran, Iran (No: 5379). The plant aerial parts were air dried at room temperature and made into powder using a blender. The aqueous, hydroalcoholic and etheric extracts were obtained by maceration of the $200 \mathrm{~g}$ plant powder with $1 \mathrm{~L}$ distilled water, ethanol/water (70/30) and petroleum ether for 2 days at room temperature, respectively. Extracts were filtered through a Whatman\#1 paper and the solvents were evaporated under reduced pressure at temperature below 45 ${ }^{\circ} \mathrm{C}$ with a rotary evaporator. Then the filtrates were lyophilized in a lyophilizator and stored under light protection and low temperature $\left(-4^{\circ} \mathrm{C}\right)$ prior to use.

The aqueous and hydroalcoholic extracts were then dissolved in distilled water and etheric extract was dissolved in dimethyl sulfoxide (DMSO). The extracts were administered orally (4 $\mathrm{mL} / \mathrm{kg}$ ) to rats at dosages of 100 and $400 \mathrm{mg} / \mathrm{kg}$.

\section{Experimental animals for gastric ulcer}

100 adult healthy male rats of Sprague Dawley strain weighing 200-250 g were housed in stainless steel cages and allowed to adapt to the conditions of the animal house for 14 days before the experiments. Animals were divided randomly into 10 equal groups of 10.24 hours before the experiment, the rats were fasted and allowed access to water. Their access to water was inhibited for 2 hours before the start of experiment.

\section{Gastric ulcer induction by ethanol}

The experimental protocol is detailed below: Normal control group (NC) was left without treatment. Standard control group (SC) received omeprazole $(20 \mathrm{mg} / \mathrm{kg}$ ) orally. Experimental groups were orally administered with aqueous extract at $100 \mathrm{mg} / \mathrm{kg}$ (AE100) and $400 \mathrm{mg} / \mathrm{kg}$ (AE400), hydroalcoholic extract at $100 \mathrm{mg} / \mathrm{kg}$ (HA100) and $400 \mathrm{mg} / \mathrm{kg}$ (HA400) and etheric extract at $100 \mathrm{mg} / \mathrm{kg}$ (EE100) and $400 \mathrm{mg} / \mathrm{kg}$ (EE400). Vehicle control group (VC) received DMSO (4 mL/ $\mathrm{kg}$ ) orally. After one hour all the rats (except normal control group) and also ulcer control group (UC) were orally administered with $75 \%$ ethanol $(4 \mathrm{~mL} / \mathrm{kg})$.

After one hour, rats were sacrificed by an overdose of ether and stomachs were isolated and cut open along the greater curvature. Stomachs were gently rinsed with $0.9 \%$ normal saline solution to remove gastric contents and blood.

\section{Gross evaluation of gastric lesions}

The ulcer area $\left(\mathrm{mm}^{2}\right)$ of each individual hemorrhagic lesion was measured and analyzed using computer software (Axiovision, Carl Zeiss Microimaging GmbH, Germany). According to the method of Andrade et al. (9), a score for the ulcer was noted and the ulcers were classified as: Level I ulcer area〈1 mm²; Level II ulcer area=1-3 mm²; Level III ulcer area $>3 \mathrm{~mm}^{2}$.

The following parameters were determined:

Ulcerative lesion index $(U L I)=1 \times$ (number of ulcers level I) $+2 \times($ number of ulcers level II) $+3 \times$ (number of ulcers level III).

Percentage protective ratio=100-[ULI pretreated]/ [ULI control]×100.

\section{Histopathological evaluation}

A portion of gastric tissue was collected from animals and fixed in 10\% neutral buffered formalin, embedded in paraffin, sectioned at $5 \mu \mathrm{m}$ and stained with haematoxylin and eosin (H\&E) for light microscopic examination.

\section{Preparation of homogenate}

Tissue homogenates were prepared for the PGE 2 MDA, TAC and HSP7O assays in gastric tissue of experimental groups. All the processes were handled at $4^{\circ} \mathrm{C}$ throughout according to previous study (10). The gastric mucosa was weighed, minced with scissors, and homogenized using $0.1 \mathrm{M}$ phosphate buffer ( $\mathrm{pH}$ 7.4) (5 cc for each $\mathrm{g}$ of tissue) in homogenizer. After centrifugation at 2000-3000 rpm for $20 \mathrm{~min}$, the supernatant was extracted and frizzed in $-80{ }^{\circ} \mathrm{C}$ for later use.

\section{Measurement of $P G E_{2}$}

The supernatants were subjected to a $\mathrm{PGE}_{2}$ assay using a rat $\mathrm{PGE}_{2}$ Eliza kit (Shanghai Crystal Day Biotech Co., LTD).

\section{Measurement of membrane lipids peroxidation (MDA)}

Tissue malondialdehyde (MDA) ( $\mathrm{mmol} / \mathrm{L})$ was determined according to the method of Lykkesfeldt. A reaction mixture containing $8.1 \%$ sodium dodecyl sulfate, $20 \%$ acetate buffer $(\mathrm{pH} 3.5)$ and $0.8 \%$ thiobarbituric acid (TBA) was mixed well 
with $0.2 \mathrm{~mL}$ of stomach tissue homogenate for $3 \mathrm{~min}$ and then incubated at $95^{\circ} \mathrm{C}$ for $60 \mathrm{~min}$. After cooling with running water, the TBA-reactive substance (MDA) was extracted with $1 \mathrm{~mL}$ of $\mathrm{H}_{2} \mathrm{O}$ and $2.5 \mathrm{~mL}$ of n-butanol: Pyridine mixture (15:1, $\mathrm{v} / \mathrm{v})$. The upper organic layer containing the MDA, which was produced by lipid peroxidation, was measured at $532 \mathrm{~nm}$ $(11,12)$.

\section{Measurement of total antioxidant capacity (TAC)}

Determination of total antioxidant capacity (TAC) in tissue homogenate by commercial kit (Labor Diagnostika Nord (LDN) Com, Nordhorn, Germany) was based on the reaction of peroxides with peroxidase followed by a color reaction of the chromogenic substrate tetramethylbenzidine. The change in color was measured colorimetrically at $450 \mathrm{~nm}$ and expressed as millimoles per liter.

\section{Measurement of heat shock protein 70 (HSP70)}

The supernatants were subjected to a HSP70 assay using a rat HSP Eliza kit (Shanghai Crystal Day Biotech Co., LTD).

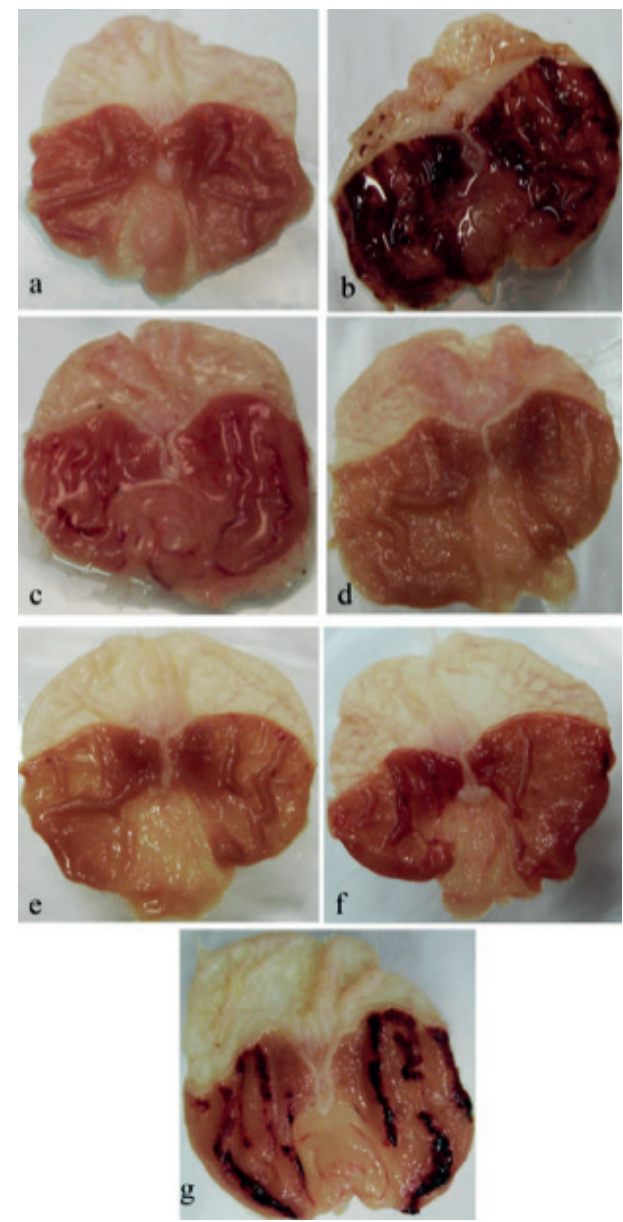

Figure 1. The effects of $S$. striata extracts on ethanol-induced gastric ulcer. a) Normal control group; b) Ulcer control group; c) Rats treated with omeprazole; d) Rats treated with aqueous extract at $400 \mathrm{mg} / \mathrm{kg}$; e) Rats treated with $100 \mathrm{mg} / \mathrm{kg}$ aqueous extract; f) Rats treated with 400 $\mathrm{mg} / \mathrm{kg}$ etheric extract; g) Rats treated with $400 \mathrm{mg} / \mathrm{kg}$ hydroalcoholic extract

\section{Statistical analysis}

The results were expressed as mean \pm standard deviation (SD). The data were analyzed statistically by one-way ANOVA with Tukey's post-hoc test, using SPSS software, version 20. $\mathrm{P}<0.05$ was considered as significant.

\section{Animal ethics}

This experiment was accomplished under the approval of the state committee on animal ethics, Shiraz University, Shiraz, Iran. Also, the recommendations of European Council Directive (86/609/EC) of November 24, 1986, regarding the standards in the protection of animals were used for experimental purposes.

\section{RESULTS}

\section{Gross evaluation of gastric lesions}

Gastroprotective effects of S. striata extracts on ethanolinduced gastric ulcer are shown in Figure 1 and Table 1. The ulcer control rats showed severe mucosal injury with ulcer area $20.75 \pm 11.09 \mathrm{~mm}^{2}$. In the rats treated with aqueous and

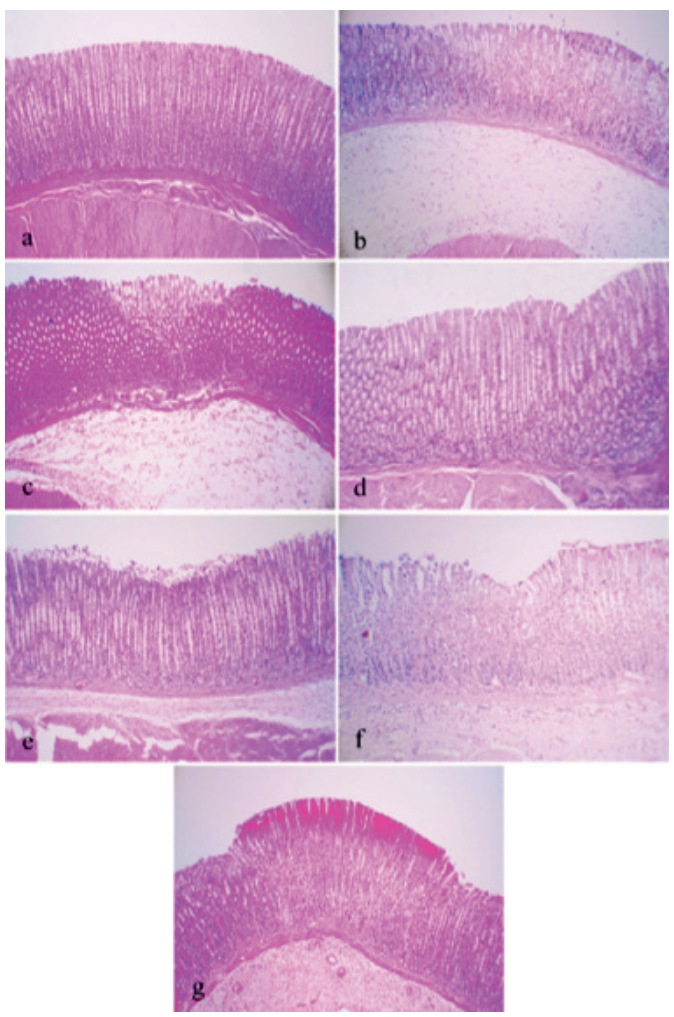

Figure 2. Histopathological evaluation of gastric tissue sections of rats. a) Normal control group: No lesion was seen; b) Ulcer control group: Mucosal necrosis, severe edema with leukocytes infiltration in submucosal layer; c) Rats treated with omeprazole: Mild mucosal damage with moderate edema and infiltration of leukocytes in the submucosal layer; d) Rats treated with aqueous extract at $400 \mathrm{mg} / \mathrm{kg}$ : No edema and leukocyte infiltration was seen; e) Rats treated with 100 mg/kg aqueous extract: Mild edema and little leukocyte infiltration in the submucosal layer; f) Rats treated with $400 \mathrm{mg} / \mathrm{kg}$ etheric extract: Mild mucosal damage with mild edema and infiltration of leukocytes; g) Rats treated with $400 \mathrm{mg} / \mathrm{kg}$ hydroalcoholic extract: Moderate edema and infiltration of leukocytes in the submucosal layer with mucosal necrosis. H\&E, $\times 80$ 
etheric extracts, the ulcer area was significantly reduced in a dose-dependent manner $(p<0.05)$. The ulcer area was significantly decreased from $20.75 \pm 11.09 \mathrm{~mm}^{2}$ in ulcer control group to $1.00 \pm 0.86 \mathrm{~mm}^{2}$ in the rats treated with $400 \mathrm{mg} / \mathrm{kg}$ of aqueous extract. Also, in the rats treated with omeprazole, a decrease was observed in ulcer area $\left(5.70 \pm 4.47 \mathrm{~mm}^{2}\right)$. Although the ulcer area in all groups had statistically significant difference with the rats treated with hydroalcoholic extract and ulcer control group, the significant inhibition of gastric ulcer in rats treated with aqueous and etheric extracts of S. striata was comparable to omeprazole (a standard drug used for gastric ulcer).

\section{Histopathological evaluation of gastric lesions}

No lesions were observed in the tissue sections from the rats of normal control group (Figure 2a), while the rats of ulcer control group showed extensive damage to the gastric tissue, including mucosal hemorrhage and necrosis, severe edema and leukocyte infiltration in the submucosal layer (Figure 2b).

In the rats treated with omeprazole, mild mucosal damage with moderate edema and infiltration of leukocytes in the submucosal layer was observed (Figure 2c).

The tissue sections of the group treated with aqueous extract at $400 \mathrm{mg} / \mathrm{kg}$ was near-normal architecture and no edema and leukocyte infiltration were seen. The rats treated with $100 \mathrm{mg} / \mathrm{kg}$ aqueous extract showed the normal glandular pattern with mild edema and little leukocyte infiltration in the submucosal layer (Figure 2d and 2e).

The tissue sections of groups treated with 100 and $400 \mathrm{mg} /$ $\mathrm{kg}$ etheric extract revealed mild mucosal damage with mild edema and infiltration of leukocytes Figure $2 \mathrm{f}$.

In the rats treated with 100 and $400 \mathrm{mg} / \mathrm{kg}$ hydroalcoholic extract, moderate edema and infiltration of leukocytes in the gastric submucosal layer with mucosal necrosis was observed in which mucosal damage was more severe at 400 $\mathrm{mg} / \mathrm{kg}$ (Figure 2g).

$\begin{aligned} & \text { Table 1. The effect of S. striata extracts in ethanol-induced } \\
& \text { gastric ulcer }\end{aligned}$
\begin{tabular}{lll} 
Group & $\begin{array}{l}\text { Ulcerative lesion } \\
\text { index }\end{array}$ & $\begin{array}{l}\text { Percentage of protective } \\
\text { ratio (\%) }\end{array}$ \\
\hline PC & $20.75 \pm 11.09^{\mathrm{a}}$ & - \\
\hline SC & $5.70 \pm 4.47^{\mathrm{b}}$ & 72.53 \\
\hline AE100 & $1.00 \pm 0.92^{\mathrm{b}}$ & 95.18 \\
\hline AE400 & $1.00 \pm .086^{\mathrm{b}}$ & 95.18 \\
\hline HA100 & $18.14 \pm 7.96^{\mathrm{a}}$ & 12.58 \\
\hline HA400 & $21.50 \pm 5.48^{\mathrm{a}}$ & 3.61 \\
\hline EE100 & $4.00 \pm 3.78^{\mathrm{b}}$ & 80.72 \\
\hline EE400 & $1.14 \pm 1.06^{\mathrm{b}}$ & 94.5 \\
\hline VC & $5.29 \pm 3.30^{\mathrm{b}}$ & 74.5 \\
\hline
\end{tabular}

Different letters indicate statistically significant differences $(p<0.05)$
In the tissue sections of vehicle group, lesions were similar to the rats treated with omeprazole.

\section{Evaluation of parameters in the gastric tissue homogenate}

The mean \pm SD of parameters values, including MDA, TAC, $\mathrm{PGE}_{2}$ and HSP70 in the gastric tissue homogenate of rats are presented in Table 2.

MDA increased in all groups in comparison with ulcer control group and the highest amount of MDA was observed in the rats of ulcer control group which showed a significant difference with all groups ( $p$ <0.05). There was no significant difference between normal control group and rats treated with aqueous extract of S. striata. The MDA level in the groups treated with other extracts and omeprazole had statistically significant difference with the normal control group and the rats treated with aqueous extract (Figure 3).

The most significant reduction in TAC was observed in rats of ulcer control group. Although the TAC level of normal control group showed a significant difference with all groups ( $p<0.05)$, this parameter increased in the rats treated with various extracts and was statistically significant in groups treated with aqueous and etheric extracts in comparison with the ulcer control group. In addition, the TAC level in rats treated with aqueous extract was higher as compared with the rats treated with omeprazole and showed significant difference (Figure 4).

Although the $\mathrm{PGE}_{2}$ level presented significant difference between normal control group and other groups, this parameter increased in the rats treated with aqueous and etheric extracts in comparison with ulcer control group and showed significant difference. There was no significant difference between the rats treated with hydroalcoholic extract and ulcer control group (Figure 5).

Table 2. The mean \pm SD of parameters value in the gastric tissue homogenate of rats

\begin{tabular}{lllll} 
Group & $\mathrm{PGE}_{2}(\mathrm{ng} / \mathrm{mL})$ & $\begin{array}{l}\mathrm{HSP} 70 \\
(\mathrm{ng} / \mathrm{mL})\end{array}$ & $\begin{array}{l}\mathrm{MDA}(\mathrm{nmol} / \\
\mathrm{mL})\end{array}$ & $\begin{array}{l}\text { TAC } \\
(\mathrm{mmol} / \mathrm{L})\end{array}$ \\
\hline $\mathrm{NC}$ & $0.26 \pm 0.01^{\mathrm{a}}$ & $0.53 \pm 0.06^{\mathrm{a}}$ & $2.96 \pm 0.11^{\mathrm{b}}$ & $2.96 \pm 0.11^{\mathrm{a}}$ \\
\hline UC & $0.13 \pm 0.01^{\mathrm{b}}$ & $0.39 \pm 0.05^{\mathrm{b}}$ & $3.66 \pm 0.18^{\mathrm{a}}$ & $1.73 \pm 0.25^{\mathrm{b}}$ \\
\hline $\mathrm{SC}$ & $0.22 \pm 0.01^{\mathrm{c}}$ & $0.46 \pm 0.04^{\mathrm{ab}}$ & $3.27 \pm 0.05^{\mathrm{c}}$ & $2.01 \pm 0.03^{\mathrm{c}}$ \\
\hline AE100 & $0.23 \pm 0.01^{\mathrm{c}}$ & $0.50 \pm 0.04^{\mathrm{a}}$ & $3.08 \pm 0.05^{\mathrm{b}}$ & $2.28 \pm 0.05^{\mathrm{d}}$ \\
\hline AE400 & $0.23 \pm 0.01^{\mathrm{c}}$ & $0.51 \pm 0.04^{\mathrm{a}}$ & $3.01 \pm 0.04^{\mathrm{b}}$ & $2.28 \pm 0.03^{\mathrm{d}}$ \\
\hline HA100 & $0.14 \pm 0.01^{\mathrm{b}}$ & $0.40 \pm 0.06^{\mathrm{b}}$ & $3.43 \pm 0.10^{\mathrm{d}}$ & $1.82 \pm 0.11^{\mathrm{b}}$ \\
\hline HA400 & $0.13 \pm 0.01^{\mathrm{b}}$ & $0.40 \pm 0.10^{\mathrm{b}}$ & $3.46 \pm 0.08^{\mathrm{d}}$ & $1.84 \pm 0.09^{\mathrm{bc}}$ \\
\hline EE100 & $0.22 \pm 0.01^{\mathrm{c}}$ & $0.48 \pm 0.04^{\mathrm{ab}}$ & $3.28 \pm 0.05^{\mathrm{c}}$ & $2.01 \pm 0.03^{\mathrm{ce}}$ \\
\hline EE400 & $0.21 \pm 0.00^{\mathrm{c}}$ & $0.47 \pm 0.03^{\mathrm{ab}}$ & $3.28 \pm 0.05^{\mathrm{c}}$ & $2.03 \pm 0.04^{\mathrm{e}}$ \\
\hline VC & $0.21 \pm 0.01^{\mathrm{c}}$ & $0.45 \pm 0.03^{\mathrm{ab}}$ & $3.07 \pm 0.03^{\mathrm{b}}$ & $2.24 \pm 0.03^{\mathrm{d}}$ \\
\hline
\end{tabular}

Different letters indicate statistically significant differences $(p<0.05)$ 
No statistically significant difference was observed in the HSP70 level between the rats treated with aqueous extract and the normal control group, but there was a significant difference between these groups with ulcer control group ( $p$ <0.05). Although this parameter increased in the rats treated with etheric extract and omeprazole, no significant difference was seen with other groups (Figure 6).

In general, the most curative effect of $S$. striata was related to aqueous extract. Although the hydroalcoholic extract resulted in improvement of some parameters, it did not have curative effects.

\section{DISCUSSION}

A key experimental model for evaluation of agents with potential anti-ulcer effect is ethanol-induced gastric injury as ethanol has been considered as a cause of gastric ulcer in humans (13). Oral administration of ethanol results in gastric mucosal damage and alterations in vascular (14). In fact, ethanol causes gastric mucosal injury via direct effects including dehydration, disruption of cellular membranes and cytotoxic effects and also indirect effects via the recruitment of leukocytes (15). In addition, ethanol leads to stasis of blood flow and disruption of gastric microvessels, which in turn inflict hemorrhage and necrosis (15.16). Ethanol-induced

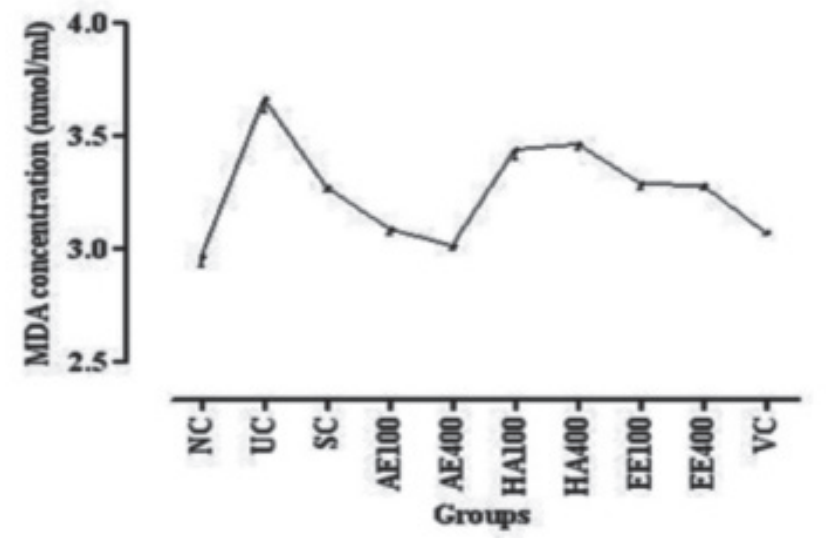

Figure 3. The effect of S. striata extracts on MDA levels in the gastric tissue homogenate of rats

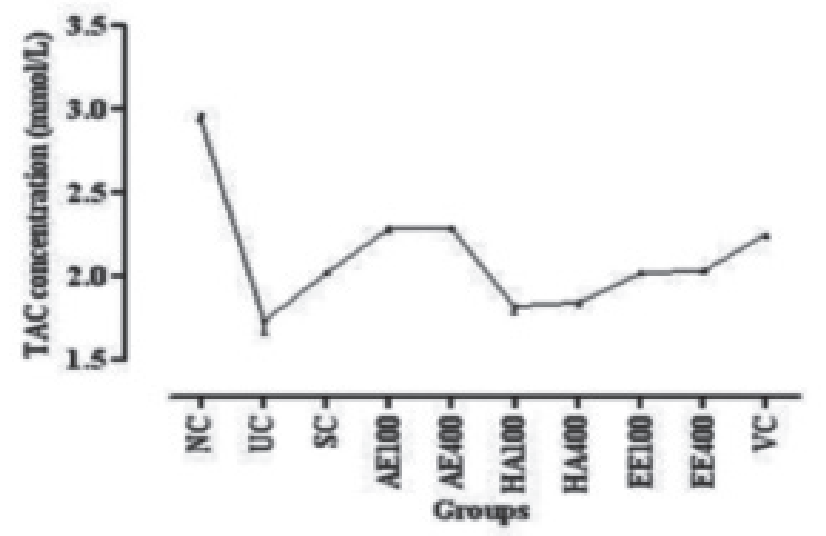

Figure 4. The effect of S. striata extracts on TAC levels in the gastric tissue homogenate of rats necrotic lesions decrease defensive factors such as the mucus production and secretion of bicarbonate (17).

The mentioned effects are probably because of biological actions like lipid peroxidation, intracellular oxidative stress, formation of free radicals, changes in permeability and depolarization of the mitochondrial membrane (18). The defensive mechanism against free radicals is weakened by ethanol (19). Ethanol consumption results in hemorrhagic damage, severe submucosal edema and epithelial cell injury. In the present study, similar lesions were also observed in gastric tissue sections of ulcer control group. The results of this study revealed aqueous extract of $S$. striata, especially at $400 \mathrm{mg} / \mathrm{kg}$ have therapeutic effects on ethanol-induced gastric ulcer as tissue structure was near-normal architecture and no edema and leukocyte infiltration were seen in tissue sections.

With both short and long-term use, omeprazole is effective in the treatment of gastroesophageal reflux and peptic ulcer disease (20). Omeprazole functions as an acid inhibitor and offers a protective role such as gastric mucosa (21). Also, this agent, as mucosal protection, is effective in the treatment of nonacid dependent models like ethanol-induced ulcer (22). In the rats treated with omeprazole. mild mucosal damage

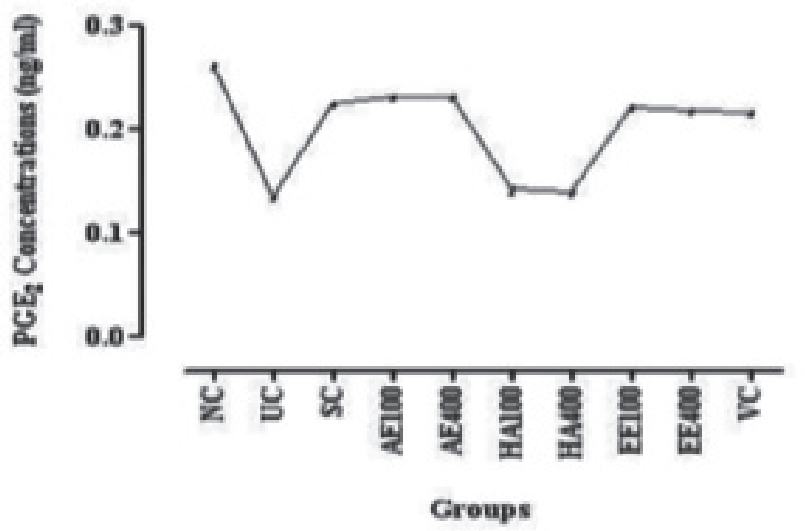

Figure 5. The effect of S. striata extracts on PGE2 levels in the gastric tissue homogenate of rats

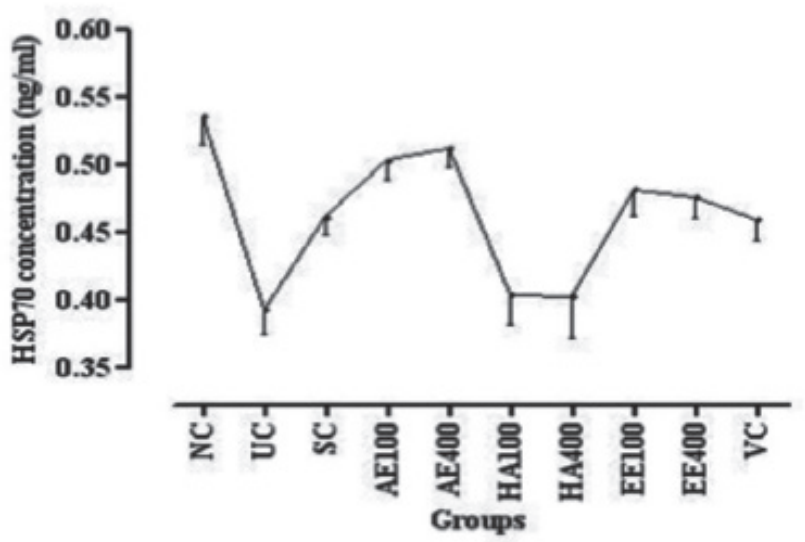

Figure 6. The effect of S. striata extracts on HSP70 levels in the gastric tissue homogenate of rats 
with moderate edema and infiltration of leukocytes in the submucosal layer were seen which were similar to those observed in the rats treated etheric extract.

Treatment of the rats with $S$. striata extract showed significant antioxidant activity by reduction of MDA and increase of the TAC level in response to ethanol-induced oxidative stress. Oxidative stress plays a key role in the pathogenesis of different diseases including gastric ulcer, and antioxidants perform a significant role in protection of gastric mucosa against necrotic injury (23). Several studies have reported the involvement of oxidative stress in the pathogenesis of ethanol-induced gastric injury $(13,15)$. Ethanol causes damage to the gastric mucosal microcirculation, resulting in hypoxia, formation of free radicals and lipid peroxidation (24). It seems free radicals formation plays an important role in the production of lipid peroxides together with interference in antioxidant activity (25). Free radicals can reduce enzyme activity such as antioxidant enzymes (26).

MDA is the final product of lipid peroxidation (27). An important pathophysiologic event in various diseases containing gastric ulcer is lipid peroxidation (28) which leads to impaired membrane integrity and ion transport, and finally, loss of cellular function. Oxygen free radicals produced in the gastric tissue might damage cell membranes and increase MDA level (29).

One mechanism involved in the healing of ulcer is removal of oxygen free radicals (Mei 30). Antioxidants like catalase and SOD are the first defensive barrier against free radicals by removing them and preventing their harmful effects (15). Various studies have reported the cytoprotective effect of some antioxidants in the healing of gastric lesions. For instance, melatonin prevented ethanol-induced gastric damage, probably because of its antioxidant effect (31).

Previous studies have shown prostaglandins affect various components of the mucosal defense, including maintaining blood flow, stimulating bicarbonate and mucus secretion, increasing the resistance of epithelial cells to injury and preventing leukocyte recruitment (32). In the present study, ethanol consumption led to decreasing $\mathrm{PGE}_{2}$ that was consistent with previous studies $(13,22) . \mathrm{PGE}_{2}$ is the most abundant prostaglandin of alimentary system which performs an important role in the regulation of gastric mucus secretion (33) and its mucosal content can be reduced by ethanol (34). $\mathrm{PGE}_{2}$ improves blood flow, actively maintaining the cellular integrity in the mucosa (34). In addition, this prostaglandin increases mucus secretion and bicarbonate to reinforce the resistance of mucosal cells to the necrotizing effect of irritants (33). The findings of the present study revealed that the gastroprotective effect of $S$. striata is related to $P G_{2}$ because its mucosal level was elevated by compound.

HSPs play an important role in both normal and pathologic situations (35). HSP70 is a $70 \mathrm{kDa}$ protein and a member of heat shock proteins family (36) which is expressed by mammalian cells. These proteins act as a molecular chaperone and protect the cellular homeostatic processes from various injurious agents through preservation of the structure of normal proteins and repair or removal of damaged proteins $(37,38)$. HSP70 protects mitochondria and interferes with the stress-induced apoptosis, resulting in cytoprotection (38). Ethanol-induced oxygen reactive species inhibit the expression of HSP70 and increase the expression of BAX, while HSP70 protects cells from oxidative stress or heat shock (39).

Jin et al. (40) reported that when the $P G_{2}$ level is decreased by NSAID, HSP70 can play an important role in gastric mucosal adaptation. In the present study, the HSP70 levels increased in various groups, which was observed as a significant difference between the rats treated with aqueous extract and ulcer control group. Oyake et al. (41) showed the overexpression of Hsp70 protects gastric mucosal against monochloramine-induced damage. Also, HSP70 induction protected rats from ethanolinduced gastric mucosal injury (15).

In conclusion, the findings of the present study indicated the efficiency of $S$. striata extract in improving free radicalsinduced injury and exerting the protective effects in ethanolinduced gastric ulcer model. These effects were related to increased $P \mathrm{PE}_{2}$ secretion, prevention of consumption of antioxidant sources and maintaining MDA at normal level.

\section{ACKNOWLEDGMENTS}

The authors would like to thank the Research Council of Shiraz University and School of Veterinary Medicine, Shiraz University for financial and technical support of this study.

\section{REFERENCES}

1. Dhasan PB, Jegadeesan M, Kavimani S, Antiulcer activity of aqueous extract of fruits of Momordica cymbalaria Hoof F. in Wistar rats, Pharmacognosy Res 2(1), 58-61, 2010.

2. Tulassay Z, Herszényi L, Gastric mucosal defense and cytoprotection, Best Pract Res Clin Gastroenterol 24(2), 99-108, 2010.

3. Srinivas LT, Lakshmi SM, Shama SN, Reddy GK, Prasanna KR, Medicinal plants as anti-ulcer agents, J Pharmacogn Phytochem 2(4), 91-97, 2013

4. Azadbakht M, Classification of Medical Plants, Tehran, Teimorzadeh Pub, p. 276-277, 2000 [In Persian].

5. Zamanian Azodi M, Ardashiri Lajimi A, Ahmadi N, Gilanchi S, Abbasi N, Hematian A, The Study of Antibiotic Properties of Scrophularia Striata Aqueous Extract on Staphylococcus aureus, J Ilam Univ Med Sci 20, 51-58, 2013

6. Monsef-Esfahani HR, Hajiaghaee R, Shahverdi AR, Khorramizadeh $M R$, Amini M, Flavonoids, cinnamic acid and phenyl propanoid from aerial parts of Scrophularia striata, Pharm Biol 48(3), 333-336, 2010.

7. Azadmehr A, Afshari A, Baradaran B, Hajiaghaee R, Rezazadeh $S$, Monsef-Esfahani $H$, Suppression of nitric oxide production in activated murine peritoneal macrophages in vitro and ex vivo by Scrophularia striata ethanolic extract, J Ethnopharmacol 124, 166-169, 2009. 
8. Mahmood AA, Mariod AA, Al-Bayaty F, Abdel- Wahab SI, Antiulcerogenic activity of Gynura procumbens leaf extract against experimentally-induced gastric lesions in rats, J Med Plant Res 4(8), 685-69, 2010.

9. Andrade SF, Antoniolli D, Comunello E, Cardoso LGV, Carvalho JCT, Bastos JK, Antiulcerogenic activity of crude extract, fractions and populnoic acid isolated from Austroplenckia populnea (Celastraceae), Z Naturforsch C 61, 329-333, 2006.

10. Yildirim A, Sahin YN, Suleyman H, Yilmaz A, Yildirim S, The role of prednisolone and epinephrine on gastric tissue and erythrocyte antioxidant status in adrenalectomized rats, J Physiol Pharmacol 58(1), 105-116, 2007.

11. Hagar HH, El-Etter E, Arafa M, Taurine attenuates hypertension and renal function induced by cyclosporine in rats, Clin Exp Pharmacol Physiol 33, 189-196, 2006

12. Zal F, Mostafavi-Pour Z, Vessal M, Comparison of the effects of vitamin $E$ and/or quercetin in attenuating chronic cyclosporine A-included nephrotoxicity in male rats, Clin Exp Pharmacol Physiol 34, 720-724, 2007.

13. Liu Y, Tian X, Gou L, Fu X, Li S, Lan N, Protective effect of I-citrulline against ethanol-induced gastric ulcer in rats, Environ Toxicol Pharmacol 34(2), 280-287, 2012.

14. Mofleh IA, Mofleh IA, Alhaider AA, Mossa J, Al-Sohaibani M, AlYahya M, Gastroprotective effect of an aqueous suspension of black cumin Nigella sativa on necrotizing agents-induced gastric injury in experimental animals, Saudi J Gastroenterol 14, 128, 2010.

15. Park SW, Oh TY, Kim YS, Sim H, Park SJ, Jang EJ, Artemisia asiatica extracts protect against ethanol-induced injury in gastric mucosa of rats, J Gastroenterol Hepatol 23(6), 976-984, 2008.

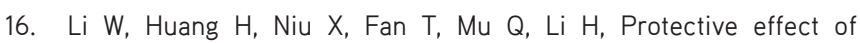
tetrahydrocoptisine against ethanolinduced gastric ulcer in mice, Toxicol Appl Pharm 272(1), 21-29, 2013.

17. Ferreira MDP, Nishijima CM, Seitoetal LN, Gastroprotective effect of Cissus sicyoides (Vitaceae): involvement of microcirculation, endogenous sulfhydryls and nitric oxide, J Ethnopharmacol 117(1), 170-174, 2008.

18. Sannomiya M, Fonseca VBM, DaSilvaetal A, Flavonoids and antiulcerogenic activity from Byrsonima crassa leaves extracts, $J$ Ethnopharmacol 97(1), 1-6, 2005.

19. Kurban S, Mehmetoğlu I, The effect of alcohol on total antioxidant activity and nitric oxide levels in the sera and brains of rats, Turk J Med Sci 38, 199-204, 2008.

20. Ode OJ, Asuzu OV, Investigation of cassia singueana leaf extract for antiulcer effects using ethanol-induced gastric ulcer model in rats, Int J PI. An and Env Sci 1, 1-7, 2011.

21. Li $X Q$, Andersson TB, Ahlstrom M, Weidolf L, Comparison of inhibitory effects of the proton pump-inhibiting drugs omeprazole, esomeprazole, lansoprazole, pantoprazole, and rabeprazole on human cytochrome P450 activities, Drug Metab Dispos 32, 821-827, 2004.

22. Golbabapour S, Hajrezaie M, Hassandarvish P, Abdul N, Hadi H, Nordin N. Acute toxicity and gastroprotective role of M. Pruriens in ethanol-induced gastric mucosal injuries in rats. Biomed Res Int doi:10.1155/2013/974185, 2013

23. Bardi DAA, Sarah Khan MA, Sabri SZ, Kadir FA, Mahmood AA, Zahra AA, Antiulcerogenic activity of typhonium flagelliforme aqueous leaf extract against ethanol-induced gastric mucosal injury in rats, Sci Res Essays 6(15), 3232-3239, 2011.

24. Huh K, Kwon TH, Shin US, Kim WB, Ahn BO, Oh TY, Inhibitory effects of DA9601 on ethanol-induced gastrohemorrhagic lesions and gastric xanthine oxidase activity in rats, J Ethnopharmacol 88(2-3), 269-273, 2003.

25. Konturek SJ, Konturek PC, Brzozowski T, Prostaglandins and ulcer healing, J Physiol Pharmacol 56(5), 5-31, 2005.

26. Pratibha R, Sameer R, Rataboli PV, Bhiwgade DA, Dhume CY, Enzymatic studies of cisplatin induced oxidative stress in hepatic tissue of rats, Eur J Pharmacol 532(3), 290-293, 2006.

27. Dursun H, Bilici M, Albayrak F, Ozturk C, Saglam MB, ALP HH, Antiulcer activity of fluvoxamine in rats and its effect on oxidant and antioxidant parameters in stomach tissue, BMC Gastroenterol 9, 36, 2009.

28. Bandyopadhyay D, Biswas K, Reiter RJ, Banerjee RK, Gastric toxicity and mucosal ulceration induced by oxygen derived reactive species: protection by melatonin, Cur Mol Med 1(4), 501-513, 2001

29. Cadirci E, Suleyman H, Aksoyetal H, Effects of Onosma armeniacum root extract on ethanol-induced oxidative stress in stomach tissue of rats, Chem Biol Interact 170(1), 40-48, 2007.

30. Mei X, Xu D, Xu S, Zheng Y, Novel role of Zn(II)-curcumin in enhancing cell proliferation and adjusting proinflammatory cytokine-mediated oxidative damage of ethanol-induced acute gastric ulcers, Chem Biol Interact 197(1), 31-39.

31. Bilici D, Süleyman H, Banoğlu ZN, Kiziltunc A, Avci B, Ciftçioğlu A, Melatonin prevents ethanol-induced gastric mucosal damage possibly due to its antioxidant effect, Digest Dis Sci 47, 856-61, 2002.

32. Miller TA, Protective effects of prostaglandins against gastric mucosal damage: current knowledge and proposed mechanisms, Am J Physiol 245(5), G601-G623, 1983.

33. Brzozowski T, Konturek PC, Konturek SJ, Brzozowska I, Pawlik T, Role of prostaglandins in gastroprotection and gastric adaptation, $\mathrm{J}$ Physiol Pharmacol 56, 33-55, 2005.

34. Zhao W, Zhu F, Shen W, Fu A, Zheng L, Yan Z, Protectiveeffects of DIDS against ethanol-induced gastric mucosal injury in rats, ABBS 41(4), 301-308, 2009

35. Arya R, Mallik M, Lakhotia SC, Heat shock genes-integrating cell survival and death, J Biosci 32(3), 595-610, 2007.

36. Ngosuwan J, Wang NM, Fung KL, Chirico WJ, Roles of cytosolic Hsp70 and $\mathrm{Hsp} 40$ molecular chaperones in post-translational translocation of presecretory proteins into the endoplasmic reticulum, J Biol Chem 278(9), 7034-7042, 2003.

37. Kim HP, Morse D, Choi AM, Heat-shock proteins: new keys to the development of cytoprotective therapies, Expert Opin Ther Targets 5, 267-287, 2006.

38. Rokutan K, Role of heat shock proteins in gastric mucosal protection, J Gastroenterol Hepatol 15, D12-D19, 2000.

39. Suemasu $S$, Tanaka K, Namba T, Ishihara T, Katsu T, Fujimoto M, A role for HSP7O in protecting against indomethacin-induced gastric lesions, J Biol Chem 284(29), 19705-19715, 2009.

40. Jin M, Otaka M, Okuyama A, Itoh S, Otani S, Odashima M, Association of $72-\mathrm{kDa}$ heat shock protein expression with adaptation to aspirin in rat gastric mucosa, Digest Dis Sci 44(7), 1401-1407, 1999.

41. Oyake J, Otaka M, Matsuhashi T, Jin M, Odashima M, Komatsu K, Over-expression of $70-\mathrm{kDa}$ heat shock protein confers protection against monochloramine-induced gastric mucosal cell injury, Life Sci 79(3), 300-305, 2006. 